\title{
Ideology and Immigration Patterns in European Union (1988-2015)
}

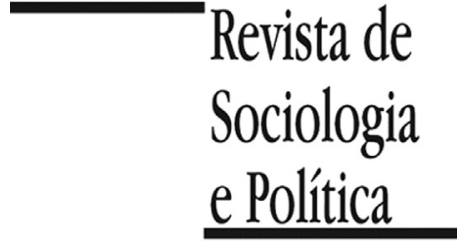

DOI $10.1590 / 1678-987319277203$

\author{
Marcelo de Almeida Medeiros' (iD, \\ Dalson Britto Figueiredo Filho'id, \\ Mariana Batista da Silva' id, \\ Cinthia Regina Campos Ricardo da Silva"iD, \\ Sidney José Vasconcelos Rosendo da Silva"ll id \\ e Natália Coêlho de Souza Oliveira"l' iD \\ 'Departamento de Ciência Política, Universidade Federal de Pernambuco, Recife, PE, Brazil. \\ IIInstitute of Humanities and Literature, Universidade da Integração Internacional da Lusofonia Afro-Brasileira, Salvador, BA, \\ Brazil. \\ IIIPrograma de Pós-Graduação em Ciência Política, Universidade Federal de Pernambuco, Recife, PE, Brazil.
}

ABSTRACT Introduction: The theory points out to the existence of likely links between party ideology and migratory policies, stating that, in principle, values associated with the right, based on nationalism, tend to, restrict immigration dynamics more than those linked to the axiology of the left, anchored in universalism. Does party ideology affect immigration patterns in the European Union? This paper tests the hypothesis that the greater the values in ideology (right-wing governments), the smaller the number of migrants to that specific country. Materials and Methods: The research design replicates secondary data from both a parliament and government database (ParlGov) and the Comparative Manifesto Project. We also use data from the Global Bilateral Migration Database and Bilateral Migration Matrix. Besides the descriptive statistics, we examine the relationship between ideology and migration flows. We estimated two regression models to deal with the following dependent variables: net migration and refugee population by country or territory of asylum. Results: Using data from ParlGov, Manifesto, and QoG, descriptive statistics has stressed a very heterogeneous cartography of political features, ideology, and migration in European Union countries. The first regression analysis using aggregate data suggests that the greater the values of ideology per country (right-wing oriented), the lower the number of people entering that country. However, the findings from our disaggregated statistical analysis, particularly Model 1, indicate no effect of cabinet ideology on net migration. As for the refugee category for immigrants, our results suggest that right-oriented national governments are less receptive to refugees. Model 2 stated that a one-point increase in ideology is associated with a 13\% average reduction in the number of refugees entering the country. Discussion: This study advances our current understanding about the relationship between party ideology and immigration patterns. Nonetheless, the results of the regression analysis show limited evidence in favor of our hypothesis that the more to the right of the ideological spectrum governments are, the lower the number of refugees they will accept. However, this analysis is only meant to show a relationship between ideology and migration. Causal claims should be interpreted with caution.

KEYWORDS: European Union; government; ideology; migration; political parties.

Recebido em 30 de Agosto de 2018. Aprovado em 27 de Abril de 2019. Aceito em 17 de Junho de 2019.

\section{Introduction ${ }^{1}$}

\footnotetext{
${ }^{1}$ This research was funding by the National Council for Scientific and Technological Development - CNPq (Grant: 443204/2015-2). We thank the anonymous reviewers of the Revista de Sociologia e Política for their comments on this article.
}

$\mathrm{T}$ The permeability of borders has increased with the process of globalization (Kogut 1991; Aman 1994; Simmons \& Piché 2002). Goods, capital, and individuals circulate with greater ease, demanding the transformation of the political, social, and economic standards of governance (Munck 2008). However, this transformation elicits different ideological paths. Even if the classic polarization between the right and the left has been attenuated, both approaching after the fall of the Berlin Wall, significant nuances still mark them regarding their conceptions of the functions of the State (Bobbio 1994).

The literature suggests a correlation between party ideology and immigration (Fitzgerald, Leblang \& Teets 2014). For example, after studying right-wing 
parties in Scandinavia, Anderson (1996, p.505) concludes that migratory pressure matters in voters' choices for these parties. Similarly, Arzheimer (2009) argues that the systems that offer minimal benefits and low unemployment and immigration rates are those that predict the lowest levels of extreme right support. Fisher (2009, p.465) highlights that some elements such as conservatism, liberalism, Christian democracy, nationalism, and libertarianism have been included on the right-wing ideological and philosophical spectrum. Still, Schweisguth (2001, p.203) indicates three possible cleavages: (i) state interventionism / economic liberalism; (ii) religious traditionalism / profane liberalism; (iii) universalistic humanism / rigorist nationalism.

The theory points to the existence of possible links between party ideology and migratory public policies, stating that, in principle, values associated with the right tend to, based on nationalism, restrict immigration dynamics more than those linked to the axiology of the left, anchored in universalism.

Does party ideology affect immigration patterns in the European Union? This paper tests the hypothesis that the greater the values in ideology (rightwing governments), the smaller the number of migrants to that specific country. The research design replicates data from a parliament and government database (ParlGov) and the Comparative Manifesto Project. We also use secondary data from the Global Bilateral Migration Database and Bilateral Migration Matrix.

The remainder of this paper is organized as follows. Section 2 reviews the literature on immigration and party ideology in Europe. We are particularly interested in the theoretical framework linking ideology and migration flow. Section 3 describes the main features of our research design - data and methods - in order to increase transparency and reproducibility (King 1995; Janz 2016). Section 4 summarizes the descriptive statistics for three secondary datasets and proposes a regression analysis. Section five concludes this work with some final remarks.

\section{Immigration and Party Ideology in Europe}

${ }^{2}$ Dataset considering the number of asylum applications. Source: http://ec.europa.eu/eurostat.

${ }^{3}$ For more information on Frontex, see: https://frontex.europa.eu/about -frontex/origin-tasks/

${ }^{4}$ For a more specific discussion on intolerance
According to official data ${ }^{2}$, from mid-2014 to 2015 about 1.7 million immigrants have arrived in Europe. Most of the immigrants crossed the border from Africa and Middle East through Mediterranean Sea motived by civil wars in their countries of origin, and this is especially true for the Syrian Civil war. This involuntary migration flow has brought the continent new challenges in terms of governance and public policy.

Vice-President of the European Commission Federica Mogherini has characterized the problem as the greatest structural phenomenon of modern times, stressing the need for European institutions to act with precision to raise efforts to address the problem which, according to her, should not be perceived by the continent as a temporary emergency. The creation in 2016 of the European Border and Coast Guard Agency, named as Frontex, is the most recent action taken by the European Council to improve border control and the cooperation with national governments close to Mediterranean $\mathrm{Sea}^{3}$.

Since the creation of Frontext, the number of irregular immigrants crossing in EU has decreased in $80 \%$. The high number of deaths in the border crossing attempts as well as the strengthening of border control and of the deportation policies are considered possible causes for the recent numbers. In addition, the recent overall raise of the right-wing coalitions in several European countries also might reflects an increase in the intolerance levels to the presence of immigrants ${ }^{4}$. Italian government is the main example of a right-wing coalition which established stricter rules for rescue and acceptance of irregular immigrants in 
toward immigrants and other minority groups in Europe, see Candeias (2006).

5 Source:

https://www.bbc.com/news/w orld-europe-46764500, accessed on February 20, 2020

${ }^{6}$ Garand, Xu \& Davis (2017) uses regression models to test support of welfare state spending, including support for specific social programs and their perception of immigrants. They use a survey data set from Cumulative American National Election Studies, from 1992 to 2012.

7 Markaki \& Longui (2012) use the European Social Survey and EU Labor Force Survey for the years 2002 , 2004, 2006 and 2008. the Mediterranean Sea ${ }^{5}$. Such a context has encouraged academics and managers to raise assumptions about possible political relations around the issue.

According to Franchino (2009), several approaches have tried to explain the migration flows, whether through systemic factors, such as economic stability and post-war transhumance or domestic variables, national policies, and cultural conflicts, for example. However, when a complex decision-making arrangement such as the European Union is added to the analysis, it is not possible to discard completely any of those variables. In fact, the European Union is submitted to a supplementary level of power - Brussels - which makes all decision-making processes much more intricate.

The level of tolerance of national citizens towards immigrants is also portrayed in the literature as an important variable explaining public opinion in policy formulation. Garand, Xu \& Davis (2017) assert that previous studies have identified that an increase in migration flows decreases support for a stronger welfare state, which could mean the rejection of leftist parties in elections, since they are often associated with robust states. This occurs because of the increase in racial and ethnic heterogeneity of the community, which also might be correlated to a lower sense of national identity and solidarity (Garand, $\mathrm{Xu} \&$ Davis 2017, p.7). Following Garand, Joppke (2003) suggests that citizenship legislation matters for the migration issue. He, however, associates the making of such legislation with the political choice of the State and not with its national or cultural specificities. That is, for Joppke:

"center-left governments will make citizenship more inclusive, center-right governments will make it more restrictive for immigrants, and right-wing governments will be more concerned with the citizenship of expatriates" (Sredanovic 2016, p. 440).

The authors identify race as a crucial variable in the United States - unlike Europe - since U.S. citizens perceive immigrants and their descendants, especially those of African origin, as the main beneficiaries of a stronger welfare state. In sum, stereotypes of immigrants, misperception of their professional skills and of their economic situation, and racism are important criteria for understanding American's conception of how the State and its institutions should function ${ }^{6}$.

As said above, this discussion is even more complex when we turn to a regional context. Markaki \& Longhi (2012) investigate how local characteristics impact attitudes towards immigration. For example, why does the level of tolerance toward immigrants vary so much between countries under the European Union governance system regardless of migration flows? The authors propose a new cross-country methodology combining individual and aggregate data sets to explain the anti-immigrant attitudes ${ }^{7}$. Instead of using countries as main cases, Markaki \& Longui (2012) use two different data sets that sort the cases by regional characteristics, not only by individual and domestic, but also by anti-immigrant perception.

Despite the confirmation that older and less educated individuals hold stronger anti-immigration attitudes, especially when it concerns immigrants outside the EU, the authors found that:"people living in big cities are less likely to view immigration as harmful, whereas respondents living in rural areas are more prone to express feelings of threat" (Markaki \& Longui 2012, p.15).

But this context is only true if the immigrants are working and if there are opportunities to promote inter-group contact, decreasing cultural conflicts.

The results of Markaki \& Longui (2012) also suggest that it is not only economic growth and unemployment rates that influence the identification of immigrants as a threat, but also a native's misperception of the overall situation of 
8 The United Kingdom and the Netherlands are considered outlier cases. Franchino (2009) points out that these two cases began to increase the immigration control already in the 1960 s, hence their immigration rates. the immigrant (their professional skills, their origins, and even their migration flow). Finally, regarding the recent increase in international migration flows, the authors suggest future research should analyze the local conditions for natives to support immigration separately to EU and non-EU immigrants. According to Markaki and Longui (2012), attitudes toward immigration seem to diverge depending on the origin of the migrant.

The literature has also tried to identify how national policies of immigration control might be influenced by migration flows. Based on the Organization for Economic Co-operation and Development (OECD) dataset, Franchino (2009) identified, using a factor analysis, two main immigration trends among European countries since the 1960s. The first trend, which includes Austria, Belgium, Denmark, France, Germany, Luxembourg, Sweden, and Switzerland, presents a discontinuous rate of immigration, with peaks and troughs in the period; the second trend, which includes Ireland, Greece, Italy, Portugal, Spain, and Norway, has experienced reversed flows; whereas they had high-emigration flows, especially before the European expansion, recently they have become a destination for immigrants. One possible reason for those different trends in immigration rates, especially for the first group, is the implementation of more restricted immigration policies (Franchino 2009, p.405) ${ }^{8}$.

Therefore, the author discusses if and how those policies can be effective in controlling the migration flows. Despite the literature's assertion that mechanisms to restrict the migration flows can only be imperfect Messina (2007, apud Franchino 2009) affirms that research focusing on domestic institutions such as (i) the legislative and executive branches, (ii) agenda-setting and veto powers, and (iii) the whole decision-making process could better explain how and when immigration policy control might vary over time, between countries, and even within government coalitions. For instance, some ministers and legislators might set up immigration restriction laws based on a particular country of origin and professional skills, while trying to attract skilled migrants from other countries (Franchino 2009, p.410).

Regarding previous studies, it is possible to assert that the characteristics of both the natives and the immigrants matter for how citizens reacts to the increase in immigration flux. As Markaki \& Longui (2012) affirm, the country of origin and status of the immigrant are important variables for identifying the effects of immigration in both national and international arenas. When the immigrant has a refugee status, specific asylum policies need to be discussed and applied to address the problem. According to the authors, this aspect also might impact on citizens' electoral behavior. Dummet (2001) affirms that illegal immigrants have similar characteristics: they are poor, and they are usually fleeing serious problems in their countries of origin, i.e. economic crisis and violence derived from civil wars. For most of them, the costs of waiting for the asylum process to be successfully concluded are too high.

Indeed, refugee status, forged by the 1951 Geneva Convention (as amended by the 1967 Protocol) is very restrictive and reflects concerns rooted in the Cold War. As Peter Burnell stresses:

\footnotetext{
"the majority of involuntary migrations have arisen in the Third World, following war, civil war, or general civil disorder, often producing an indiscriminate deprivation of basic human rights and economic destruction" (Bunell 2009, p.454)
}

Petiteville (2012, p.350) stresses that three-quarters of asylum seekers are not granted refugee status. As a matter of fact, they are denied the right to asylum and become de facto persons in an irregular situation in the country where they have applied for refugee status. 
9 The United Nation Refugee Agency (UNHCR) defines two categories of migrations: voluntary (the individual choose to leave his/her country of origin to pursue a better quality of life), and non-voluntary or forced migration (which includes internal displaced persons, stateless, exiles, asylum-seekers, and refugees). The differences among those categories are not always easy to identify, especially because the reasons to migrate are very similar, as for example political, gender or racial persecutions as well as civil wars, and failed states situation. For more detailed information, see: https://www.unhcr.org/556725 e69.pdf, accessed on February 20, 2020.

${ }^{10}$ The legal category of refugee is stated by the 1951 Geneva Convention: someone who's forced to leave her country due to persecution based on her race, religion, nationality, membership of a particular social group or political opinion. As shown in the next sections, in our empirical work net migration and refugee population by country or territory of asylum are our dependent variables. Do not confuse refugee and asylum seeker: An asylum seeker is someone who claims to be a refugee but whose claim hasn't been evaluated. This person would have applied for asylum on the grounds that returning to his or her country would lead to persecution on account of race, religion, nationality or political beliefs. Someone is an asylum seeker for so long as their application is pending. So not every asylum seeker will be recognised as a refugee, but every refugee is initially an asylum seeker. Cf. https://www.refworld.org/doci d/59e99eb94.html, accessed on February 20, 2020.

${ }^{11}$ For a deeper discussion on the difficulties to admit the refugees problem as an Human Rights International Regime matter, see Reis \& Menezes (2014).

${ }^{12}$ The Schegen Agreement regulates the movement of people within the countries
Accordingly, this paper considers the refugee status as a different category within the migration flow ${ }^{9}$. This category, internationally recognized and therefore legitimized, emerges consensually as a broad and common frame of reference that targets the actions of states and qualifies the attributes that define the legal migrant ${ }^{10}$. Despite the effort to define precisely the profile of the refugee, there is no guarantee that the exercise of interpretation by different governments will not be subject to the use of normative principles. This could lead to different migratory public policies relating to the refugee, which would vary within the right-left ideological spectrum. On the other hand, outside the refugee institution, there does not seem to be an international regime with legitimacy and legality and, as a result, States feel "compliance free" to adopt policies that are even if particularly so - convenient ${ }^{11}$. Coping with the illegality and / or illegitimacy of a migrant who is not a refugee can reduce the ideological gap between governments, making left-wing or right-wing public policies not significantly different. That is, migration policy would assume a supra-ideological nationalistic bias, ultimately based on citizen preference, which is, indeed, legally legitimized and legalized within the nation-state.

The legal scope of the European Union provides for several mechanisms through which community policy is established. Like the division of competences in multilevel governance, the legislative acts adopted differ from the degree of imposition of the European standard. As far as the Constitutional Treaties are concerned, only recently has the issue of migration gained prominence. The Maastricht Treaty (1993) was the first legal framework to address the issue within the European Union through the organization of institutional pillars, among which migration policy was inserted and the Schengen Agreement incorporated into the bloc ${ }^{12}$. However, until the Treaty of Amsterdam (1999), the problem of immigration in general, not to mention refugee asylum, had little influence from supranational institutions, allowing significant autonomy from the Member States. Since the Treaty of Lisbon (2007), asylum and immigration policies have been approached like any other public policy, with the supranational institutions competing for the standardization of community policy surrounding immigration and refugee asylum ${ }^{13}$. The influence of new immigration and asylum policies on national political dynamics is clear.

In The Party Politics of the EU and Immigration, Odmalm (2014) argues that political parties may find an incompatibility between their ideological positions and specific issues. Accordingly, political parties struggle to deal with "conflicting ideological pulls" (Odmalm 2011, apud Odmalm 2014), where internal ideological tensions provoke them to rethink - and perhaps change slightly - their political positions in order to maintain electoral survival. Those conflicts occur internally between leadership and externally, when the political parties compete to assert which proposition is best fit to solve a specific problem.

In order to verify if ideology matters or not, Odmalm (2014) compares the political parties manifesto positions with qualitative interviews made with members of the national parliaments and political strategists. His analysis focuses on two very relevant issues: the role of the European Union and immigration policy control. The author considers that these issues may express better the cleavages in multilevel-governance and divergences between party ideology and political pragmatism. Thus, Odmalm (2014) compares the Belgian, British, Dutch, and Swedish party systems between 1991 and 2010, considering the different dynamics inside those countries and how external critical conjectures distinctly affected them, whether with different immigration flow patterns or the relation with EU institutions.

Arriving at some overall conclusions, the author points out that ideology is still an important factor for political party competition. However, ideology may 
that have joined. Through the insertion of the agreement in the bloc, the new members of the European Union would automatically submit to the rules of circulation defined by the Schengen regime. For more details see: http://eur-lex.europa.eu/legal-c ontent/PT/TXT/?uri=URISER $\mathrm{V} \% 3 \mathrm{Al} 33020$, accessed on February $20^{\text {th }}, 2020$.

${ }^{13}$ For more details see: http://www.europarl.europa.eu /atyourservice/en/displayFtu.h ml?ftuId=FTU_5.12.2.html, accessed on July 10th, 2016.

14 By entering the following keywords in the search form: party ideology; immigration; Europe.

15 Bale (2008); Boswell (2003); Ireland (1991); Del Sarto (2016).

16 Boswell \& Hough (2008); Duncan \& Van Hecke (2008); Geddes (2008);

Green-Pedersen \& Odmalm (2008); Marthaler (2008) Hinnfors et al. (2012); Lahav (1997); Smith (2008); Geddes (1995); Gerhards \& Hans (2011); Kessler \& Freeman (2005); Kuhn (2012); Lahav \& Messina (2005); Lopatin (2013); Stockmer (2016); Thomas (2016). vary across countries and among political parties. Despite some criticism, the Manifesto is still the best dataset for identifying the ideological foundation of political parties. However, complementary methods, as indicated by Odmalm (2014), might be helpful in asserting the complexity of this theme, especially when dealing with a multilevel governance context.

Finally, the correlation between immigration flows and party ideology still represents a gap in the literature. Systematic research conducted with the journals International Affairs, Journal of European Public Policy, and Journal of Common Market Studies ${ }^{14}$ has identified only twenty papers dedicated to analyzing this issue in the European context. Four of these papers ${ }^{15}$ can be characterized as theoretical discussions and sixteen as empirical ones ${ }^{16}$. Most of them are also dedicated to the formulation, decision-making process, implementation, and efficiency of immigration policies.

Few papers investigate such problems using case studies of specific countries such as Italy (Geddes 2008), the United Kingdom and Ireland (Smith 2008), France (Martheler 2008), and Sweden (Hinfforns et al., 2012). However, there are still a large number of studies that analyze the attitudes of citizens and deputies toward migrants and a more liberal immigration control policy (Hinfforns et al., 2012; Lavah 1997, 2005; Smith 2008; Gerhards \& Hans 2011; Kessler \& Freeman 2005; Stockemer 2016).

However, only Lavah (1997) presents a clear hypothesis that proposes testing whether immigration rates are affected by party ideology. The author concludes that there is an ideological continuum range from left to right that lists the members of European parliament's preferences on immigration policy. In addition, the deepening of European Integration does not exclude the capacity of the political party system to retain and consolidate party affiliation and ideology competition. Therefore, the main research objective here is to contribute to this theoretical gap in the debate on the possible correlation between party ideology and migration flows. This paper seeks to contribute to an understanding of how ideology varies over time between countries, and how this affects their migration flows. Our main hypothesis is that the more to the right the ideology of the cabinet, the lower the migration flow. We expect that the preferences of the decisionmakers will affect actions implemented towards migration (explicit policies or institutionalized practices) and these actions conducted by the cabinet will affect in its turn the migration flow.

At this point, it is useful to distinguish ideological positioning, our main explanatory factor, from expressed policies. Ideological positioning refers to the expressed preferences of political actors concerning relevant topics such as the intervention of the State in the economy or individual rights (Laver \& Budge 1992). These preferences might be real, but they are usually interpreted as strategic since it is a signaling mechanism from political actors to voters. Manifestos are, by definition texts serving to present a party's positions to the voters (Laver \& Garry 2000; Dinas \& Gemenis 2010). Public policies are interventions designed towards a specific topic (Baumgartner \& Jones 1993).

Important to emphasize that these policies may be actual programs or institutionalized practices implemented by the State. We expect that the ideological positioning of political actors will influence policies (these may or may not be directly observable), and these policies will affect the migration flow. In this paper, we focus on the input (ideology) and the output (migration flow) of this relationship. The focus on ideological positioning is relevant because it reflects a common field of understanding between representatives and voters. Voters are supposed to choose those politicians that are closest to their own position. Once in office, representatives are expected to implement decisions that reflect their public positioning in the left-right scale. Whether this connection between the 
expressed position of the representatives and the actual migration is empirically observed is precisely our research question.

\section{Data and Methods}

${ }^{17}$ Replication materials and Appendix are available at: https://osf.io/j4gnt/

${ }^{18}$ The list of EU members may be found here: $<$ https://europa.eu/european-u nion/about-eu/countries en>, accessed on February $20^{\text {th }}$, 2020.

This section describes the data and methods ${ }^{17}$ employed to answer our research question: does political party ideology affect immigration patterns in the European Union? Table 1 summarizes the main features of our research design.

The population is composed of 28 countries whose membership was formally enacted by the European Union ${ }^{18}$. The original period covers 1988 to 2015. We start by describing the main variables from two databases (ParlGov and Manifesto $)^{19}$.

Besides the descriptive statistics, we examine the relationship between ideology and migration flows. We estimated two regression models to deal with the following dependent variables: net migration and refugee population by country or territory of asylum. For this specific reason, in the panel we employ ParlGov and QoG data only. Table 2 describes the variables' main features (original names as stated in the database and operationalization).

\section{Results}

\section{IV.1 Descriptive Statistics}

${ }^{19}$ In particular, ParlGov is "a data infrastructure for political science and contains information for all EU and most OECD democracies. The database combines approximately 1500 parties, 910 elections $(8300$ results), and 1400 cabinets(3500 parties)" (PARLGOV 2017). The Manifesto Project "provides the scientific community with parties' policy positions derived from a content analysis of parties' electoral manifestos. It covers over 1000 parties from 1945 until today in over 50 countries on five continents" (MANIFESTO

This section presents the data from the ParlGov and Manifesto projects that are used to measure ideology and immigration. As far as the ideological patterns are concerned, the numbers examined in the ParlGov dataset show that the higher the ideological value of a party, the more the party leans to the right wing. The left-right variable (data from ParlGov) presents information about the ideological trends of parties on a scale from 0 to 10 . The mean is 5.19 with a standard deviation of 2.22. The Young Lithuania, from Lithuania, was the party that stood closest to the most far right position (9.80), while The Left, from Luxembourg, was the one that was the closest to the most far left position of the scale (.53). It is important to highlight that there is no information for almost $25 \%$ of the observations. The ideological patterns - throughout the aforementioned variable - might be observed in the list of countries studied here. Figure 1 shows the variation in the ideology of the national governments in the EU.

Table 1 - Research design

\begin{tabular}{ll}
\hline Info & Description \\
\hline Population & European Union (28 member-states) \\
Time frame & 1988 to 2015 \\
Techniques & Descriptive and multivariate statistics \\
Sources & ParlGov Database \\
& Manifesto Database \\
& QoG \\
\hline
\end{tabular}

Source: Elaborated by the authors. 
Table 2 - Variables

\begin{tabular}{|c|c|c|}
\hline Source & Variable (label) & Description \\
\hline \multirow[t]{8}{*}{ ParlGov $^{\mathrm{I}}$} & country_name & Name of country in English \\
\hline & caretaker & $\begin{array}{l}\text { Caretaker cabinet with a limited legislative mandate: non-partisan, provi- } \\
\text { sional, technical or continuation (tree month rule) cabinet }\end{array}$ \\
\hline & cabinet_party & Indicates if the cabinet is composed by members of opposition parties \\
\hline & prime_minister & Indicates if the party fills the prime minister position \\
\hline & election_seats_total & Total number of seats per country \\
\hline & Seats & Number of seats per party/election \\
\hline & election_date & Date the election took place. \\
\hline & left_right & $\begin{array}{l}\text { 0-10 scale mean value in left/right dimension with data from Castles/Mair } \\
\text { 1983, Huber/Inglehart 1995, Benoit/Laver } 2006 \text { and CHES } 2010 .\end{array}$ \\
\hline \multirow[t]{6}{*}{ Manifesto $^{I I}$} & countryname & Name of country in English \\
\hline & per601 & $\begin{array}{l}\text { Favorable mentions of the manifesto country's nation, history, and general } \\
\text { appeals. }\end{array}$ \\
\hline & per602 & Unfavorable mentions of the manifesto country's nation and history. \\
\hline & Rile & Right-left position of party as given in Michael Laver/Ian \\
\hline & per601_2 & $\begin{array}{l}\text { Statement advocating the restriction of the process of immigration, i.e. ac- } \\
\text { cepting new immigrants. }\end{array}$ \\
\hline & per602_2 & $\begin{array}{l}\text { Statements favoring new immigrants; against restrictions and quotas; rejec- } \\
\text { tion of the 'boat is full' argument. }\end{array}$ \\
\hline \multirow[t]{2}{*}{$\mathrm{QOG}^{\mathrm{III}}$} & wdi_mignet & $\begin{array}{l}\text { Net migration is the net total of migrants during the period, that is, the total } \\
\text { number of immigrants less the annual number of emigrants, including both } \\
\text { citizens and noncitizens. Data are five-year estimates. }\end{array}$ \\
\hline & wdi_refasylum & $\begin{array}{l}\text { Refugees are people who are recognized as refugees under the } 1951 \text { Con- } \\
\text { vention Relating to the Status of Refugees or its } 1967 \text { Protocol, the } 1969 \\
\text { Organization of African Unity Convention Governing the Specific Aspects } \\
\text { of Refugee Problems in Africa, people recognized as refugees in accor- } \\
\text { dance with the UNHCR statute, people granted refugee-like humanitarian } \\
\text { status, and people provided temporary protection. Asylum seekers people } \\
\text { who have applied for asylum or refugee status and who have not yet re- } \\
\text { ceived a decision or who are registered as asylum seekers are excluded. Pal- } \\
\text { estinian refugees are people (and their descendants) whose residence was } \\
\text { Palestine between June } 1946 \text { and May } 1948 \text { and who lost their homes and } \\
\text { means of livelihood as a result of the } 1948 \text { Arab-Israeli conflict. Country of } \\
\text { asylum is the country where an asylum claim was led and granted. }\end{array}$ \\
\hline
\end{tabular}

Merge between Mean_Ideology_CabiParlGov and QOG net_Pond_Parties data
New variable as the result of a weighted average of the party ideology in relation to the proportion of the party number of seats per country/year.

Source: Elaborated by the authors.

IParlGov database: <http://www.parlgov.org/data/table/view_cabinet/>, accessed on March 10 ${ }^{\text {th }}, 2017$

IIManifesto database: <https://manifesto-project.wzb.eu/>, accessed on March 10 ${ }^{\text {th }}, 2017$.

IIIQGoG database: <http://www.qogdata.pol.gu.se/dataarchive/qog_std_jan15.pdf>, accessed on June 26 ${ }^{\text {th }}, 2017$.

Estonia (5.92), Slovakia (5.84) and Hungary (5.79) have the highest means, which indicates that these countries have governments associated with the far right. On the other hand, Portugal $(4,19)$, Greece $(4,45)$ and Germany $(4,54)$ have the more leftish average ideological composition.

We employ data from the Manifesto project to explore the variation of the favorable mentions of the manifesto country's nation, history, and general appeals. Figure 2 illustrates how the variable national way of life + is represented in each country. 
Figure 1 - Ideology per country

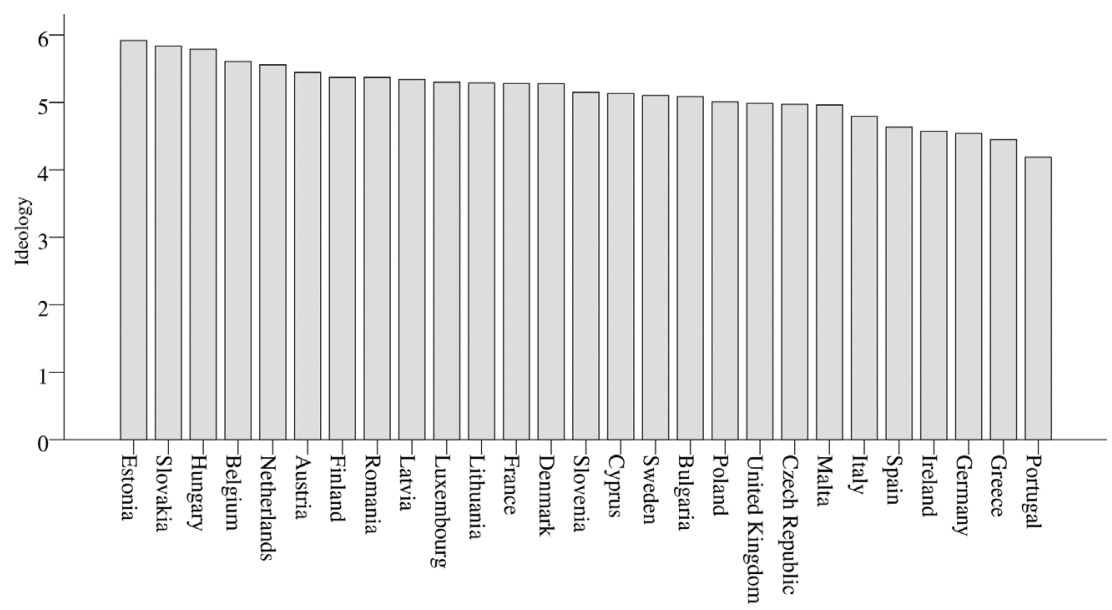

Source: Elaborated by the authors. Data from ParlGov.

Figure 2 - National way of life + (mean)

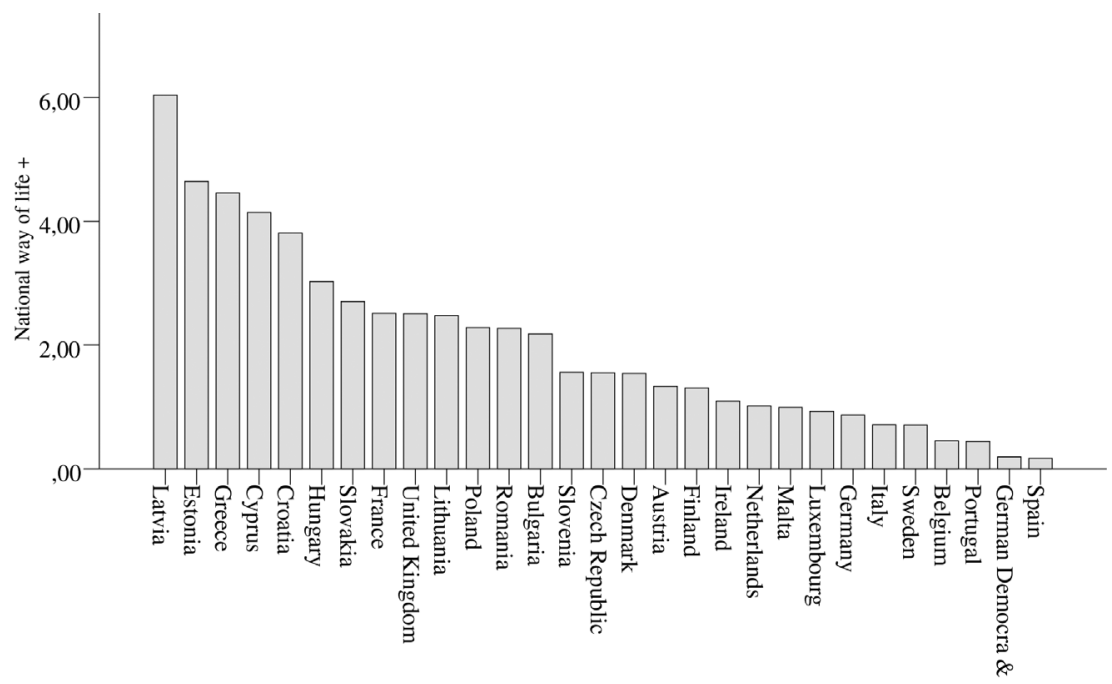

Source: Elaborated by the authors. Data from Manifesto.

Latvia presents the highest mean (6.039) while Spain presents the lowest one (.166). The higher the mean value, the more a country is composed of parties whose manifestos make mention of nationalist views. The opposite may be observed in the Figure 3 where the variable national way of life - illustrates party manifestos that do not convey nationalist views.

The United Kingdom presents the highest mean (.96) while Sweden, Slovenia, Portugal, Poland, and Malta present the lowest $(0.00)$. This indicates that the UK presents the lowest number of nationalist mentions in their party manifestos.

The right-left ideological index indicates the party position in a classification between right and left (Laver \& Budge 1992). This variable embraces 1,404 cases (with a mean of -1.35 and a standard deviation of 19.02). Its amplitude varies from -53.44 (minimum value) to 90.91 (maximum value). The lower the value, the more a party leans to the left. Figure 4 shows the mean per country from 1988 to 2015. 
Figure 3 - National way of life - (mean)

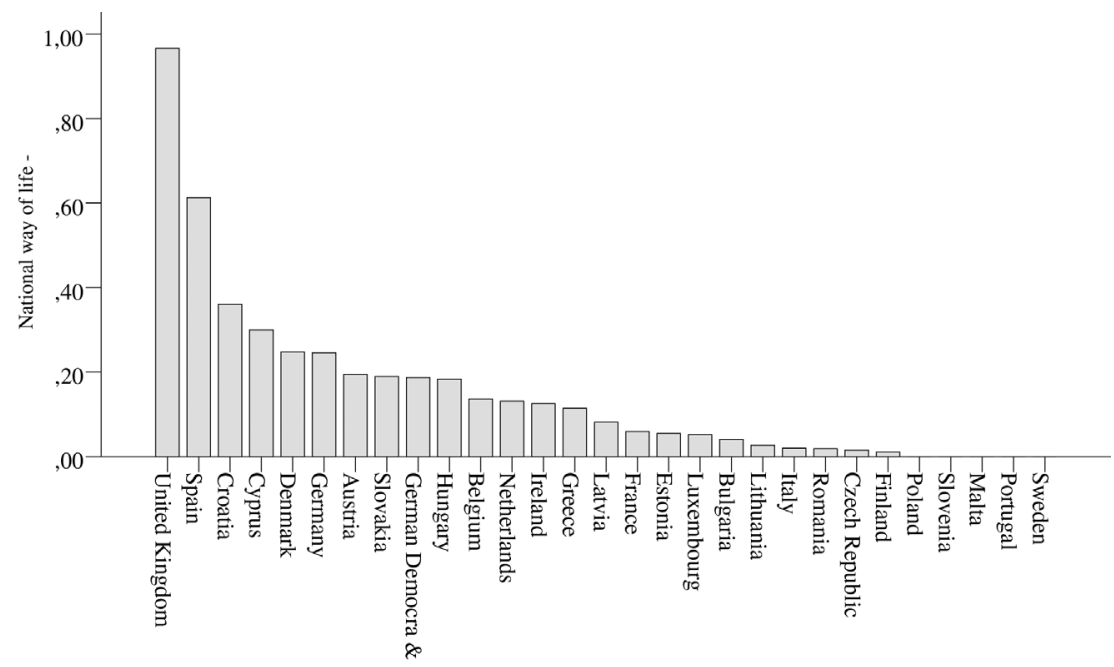

Source: Elaborated by the authors. Data from Manifesto.

Figure 4 - Manifesto right-left ideological index: mean

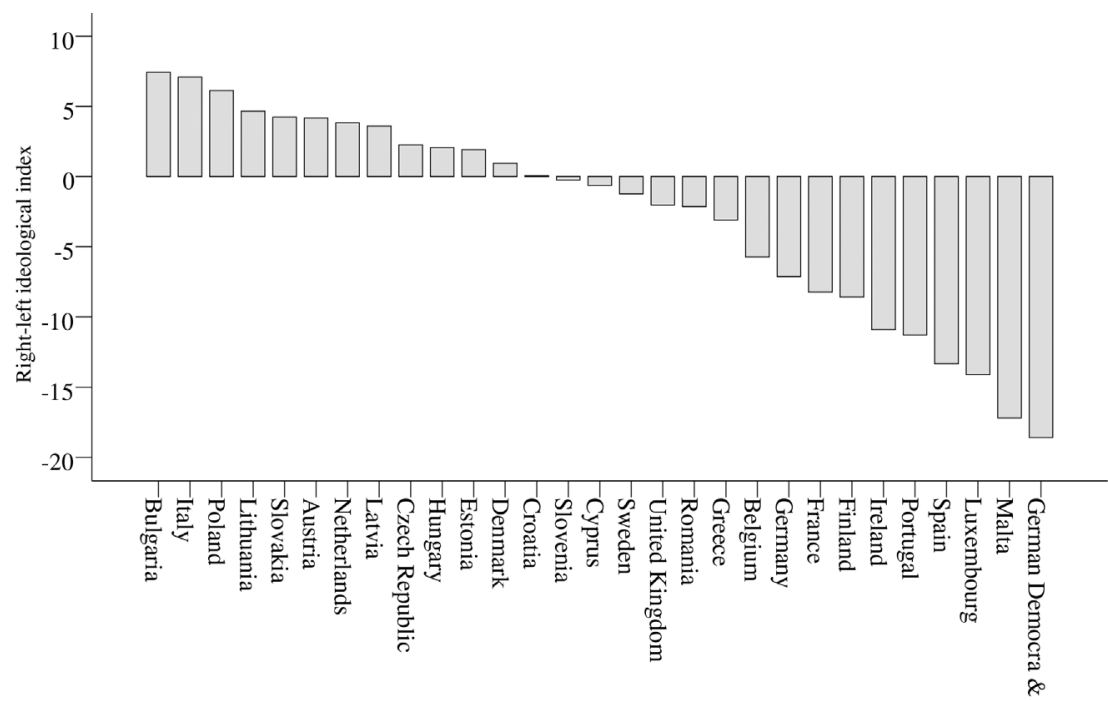

Source: Elaborated by the authors. Data from Manifesto.

Bulgaria presents the highest mean (7.43) while the German Democratic Republic presents the lowest one (-18.58). This means that Bulgaria leads the ranking of the right while the German Democratic Republic leads the left.

Aggregate level data (Figure 5) suggest that the greater the values of ideology for each country (right-wing oriented), the lower the number of people entering that country $(\mathrm{r}=-.439 ; \mathrm{n}=27 ; \mathrm{P}$ value $=.022)$.

The correlation presented in Figure 5 means that the value of the Net Migration variable (the difference between the number of people entering and leaving

${ }^{20}$ We observe interesting results by subsampling our data. For example, by excluding Greece, Ireland, and Portugal, the correlation the country) seems to be higher in leftist countries since the number of persons entering those countries overlap the number of people leaving them ${ }^{20}$.

By examining the aggregated relationship between ideology and the logarithm of number of refugees (Figure 6), we observe a weak negative correlation that is not statically significant $(\mathrm{r}=-.196 ; \mathrm{n}=27 \text {; } \mathrm{p} \text {-value }=.328)^{21}$. 
coefficient goes to -.620 (p-value <.001). In other words, the association between ideology and net migration becomes stronger. Conversely, by excluding Germany, Italy, and Spain, the negative correlation disappears and the relationship between ideology and migration is no longer statistically significant (p-value $=.417)$.

${ }^{21}$ For Germany (DEU) the number of refugees standardized value is extremely high $(z=4.78)$ and could influence coefficients' consistency. For this reason, we preferred to use logarithmic transformation.
Figure 5 - Ideology $\mathrm{x}$ net migration

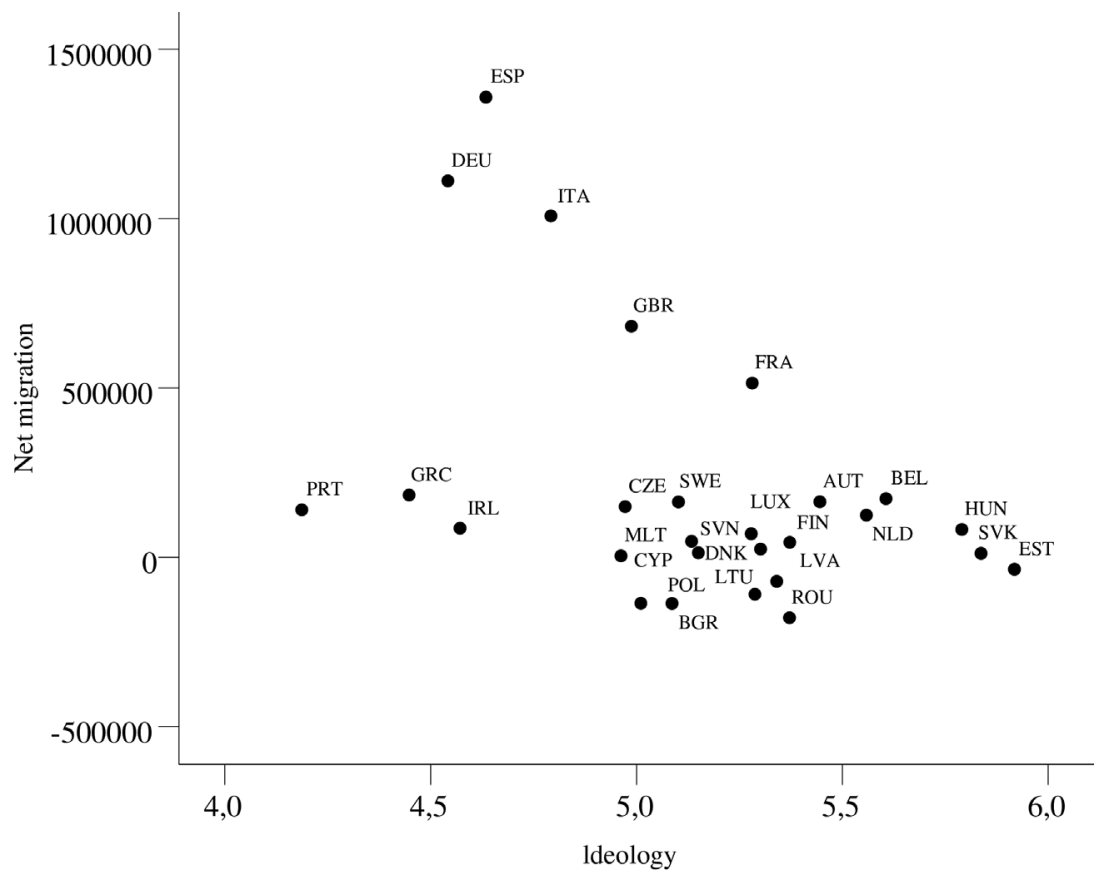

Source: Elaborated by the authors. Data from QOG and ParlGov. $\mathrm{n}=27, \mathrm{r}=-.439$, $\mathrm{p}$-value $=.022$.

Figure 6 - Ideology x refugee by territory or country of asylum

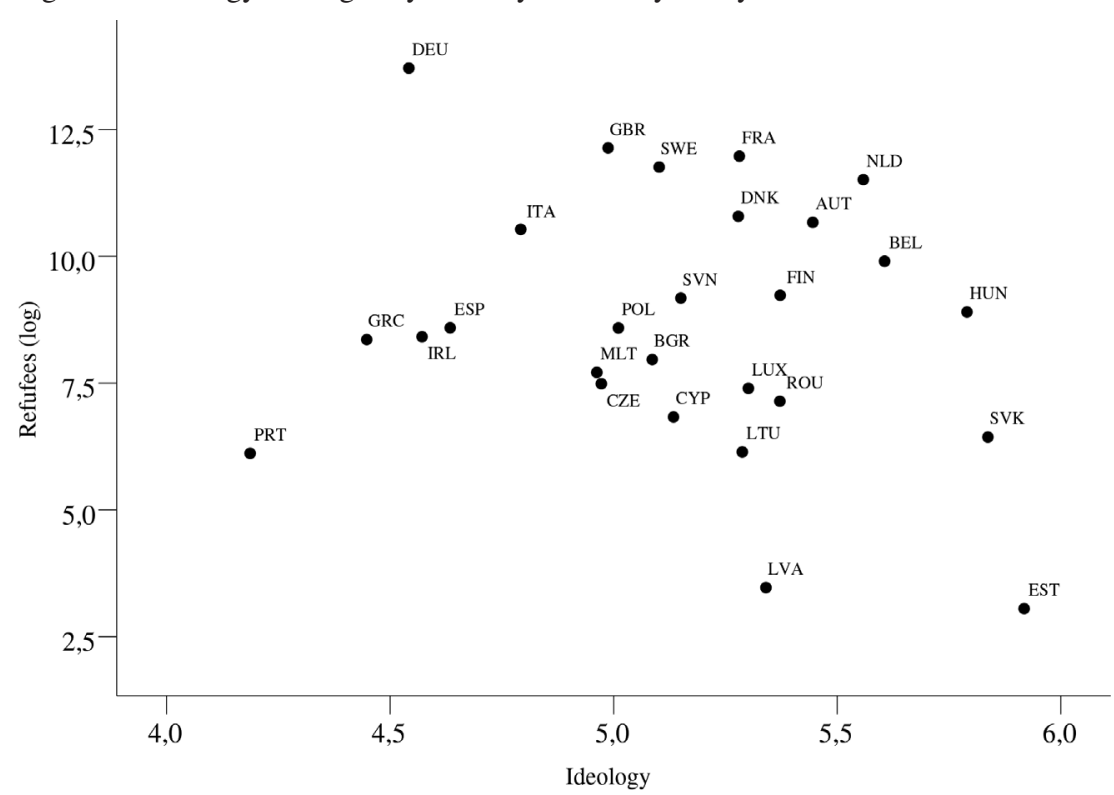

Source: Elaborate by the authors. Data from QOG and ParlGov. $\mathrm{n}=27, \mathrm{r}=-.196, \mathrm{p}$-value $=.328$

In short, our main aggregated results suggest the following: (1) the higher the the value on the ideology scale (right-wing oriented), the lower the average net migration; (2) these results are subject to change depending on specific case selection; and (3) there is no association between ideology and the refugee population. 
IV.2 Regression analysis

In this section, we examine the relationship between cabinet ideology and migration using two different specifications of the dependent variable. First, we present the results considering net migration by country and year; in the second specification, we consider refugees by country of asylum and year. The refugee variable was $\log$ transformed before inclusion in the models. Migration is a complex issue and is caused by many different factors. To take this into consideration, we include country dummy variables to hold fixed specific characteristics of the countries in the analysis such as culture, legal tradition, or socioeconomic status. Table 3 summarizes the results.

Model 1 presents the results of the effect of cabinet ideology over net migration. Our theoretical expectation was that the greater the values of cabinet ideology, meaning that the government was leaning more towards the right, the greater the reduction in the net migration of that country. However, the results indicate that there is no evidence to support rejecting the null hypothesis, meaning that the impact of cabinet ideology on net migration in the population cannot be differentiated from zero.

Model 2 shows the effect of the same ideology variable now on the number of refugees accepted in the country. The issue of refugee asylum is directly in the political spotlight considering both the humanitarian implications and also the preferences of citizens. The past elections in European Union countries were dominated by this debate of whether or not to accept refugees. Our results show that there is a statistically significant effect of cabinet ideology on the number of refugees. This result means that the greater the right-wing inclination of the cabinet, the smaller the number of refugees entering that country. Since this variable is included in the models in its log transformation, the results should be read in percentages. In light of this, we understand that 1-point increase in the ideology to be associated with a $13 \%$ average reduction in the number of refugees entering the country. Figure 7 shows the predicted values of the refugee variable, considering the different levels of cabinet ideology.

The more to the right of the ideological spectrum a government is, the smaller the number of refugees entering that country. However, as indicated by the confidence intervals, this effect is very heterogeneous in the smaller values of the ideology variable, becoming more precise in the larger values of ideology. This means that there is greater variation among the left-wing governments and more homogeneity among right-wing governments. For this reason, the

Table 3 - Ideology and immigration in the European Union

\begin{tabular}{lcc}
\hline & Model 1 & Model 2 \\
\hline VD & Net migration & Log Refugee by Asylum \\
Constant & $-123,992.5(257,497)$ & $9.199377(.3821349)$ \\
Ideology & $66,235.75(51,334.94)$ & $-.1376671 *(.0750195)$ \\
Country dummy & Yes & Yes \\
$\mathrm{R}^{2}$ (within) & .0156 & .0065 \\
$\mathrm{~F}$ & 5.01 & 156.60 \\
$\mathrm{~N}$ & 133 & 545 \\
\hline
\end{tabular}

Source: Elaborated by the authors. Data from QOG and ParlGov.

Note: Coefficients reported. Standard-errors in parenthesis.

$*$ P-value $<.10 ; * * \mathrm{P}$-value $<.05 ; * * * \mathrm{P}$-value $<.01$. 
Figure 7 - Cabinet ideology and refugees in the European Union

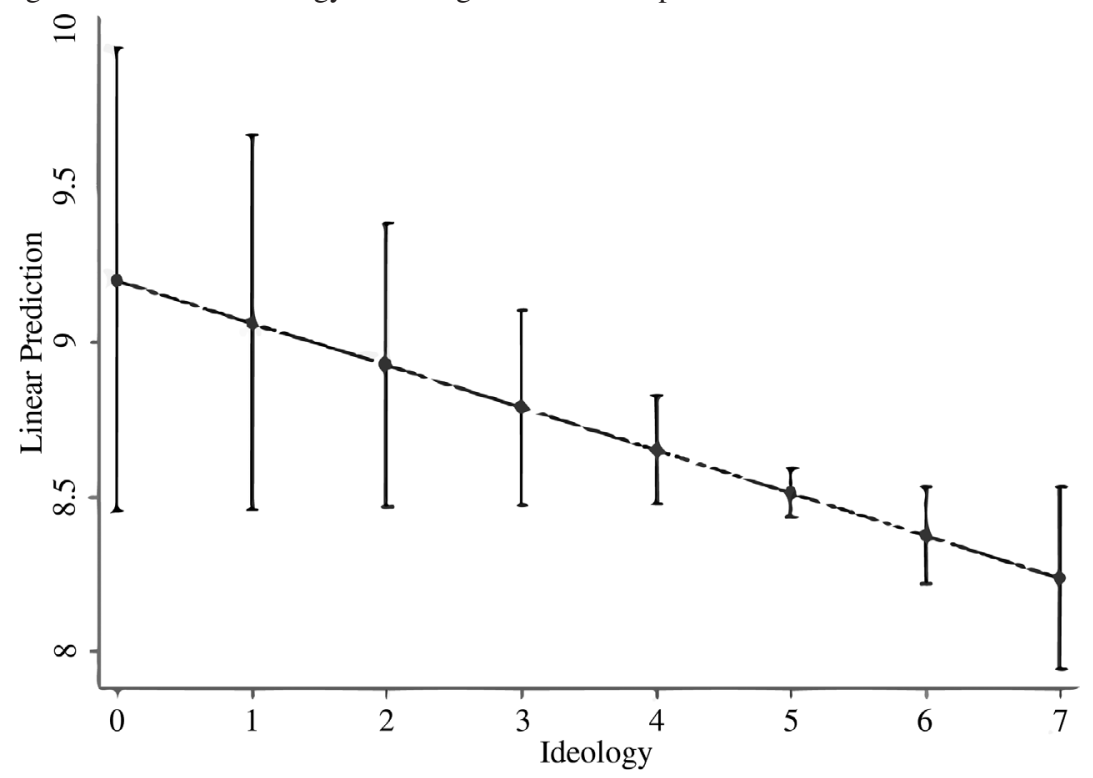

Source: Elaborated by the authors. Data from QOG and ParlGov.

mean effect of ideology on refugees by asylum is only marginally significant $(\mathrm{p}$-value $=.067)$.

In sum, our results suggest the following. Different from what we expected, there is no negative relationship between ideology and immigration flows. However, when we consider a different specification of the dependent variable (immigration patterns), we observe a negative and statistically significant association between ideology and the number of refugees entering in a particular country. In fact, we find that right-wing governments are less receptive to immigrants.

\section{Concluding Remarks}

This paper has studied a literature and presented a statistical analysis that points to the existence of possible links between party ideology and migratory public policies, stating that, in principle, values associated with the right tend to, based on nationalism, restrict immigration dynamics more than those associated with the left of the ideological spectrum, which is anchored in universalism.

Using data from ParlGov, Manifesto, and QoG, descriptive statistics has stressed a very heterogeneous cartography of political features, ideology, and migration in European Union countries. The first regression analysis using aggregate data suggests that the greater the values of ideology per country (right-wing oriented), the lower the number of people entering that country. However, the findings from our disaggregated statistical analysis, particularly Model 1, indicate no effect of cabinet ideology on net migration.

As far as the refugees' category for immigrants is concerned, our results suggest that right-oriented national governments are less receptive to refugees. Model 2 stated that a one-point increase in ideology is associated with a $13 \%$ average reduction in the number of refugees entering the country. This supports claims in the literature such as those made by Markaki \& Longui (2012) that attitudes toward immigration seem to diverge depending on the origin of the migrant. The authors highlight that the country of origin and status of the immi- 
grant are important variables to identify the effects of immigration in both national and international arenas.

This study advances our current understanding about the relationship between party ideology and immigration patterns. Nonetheless, the results of the regression analysis show limited evidence in favor of our hypothesis that the more to the right of the ideological spectrum governments are, the lower the number of refugees they will accept. However, this analysis is only meant to show a relationship between ideology and migration. Causal claims should be interpreted with caution.

The correlation between immigration flows and party ideology still represents a gap in the literature. That said, in terms of a future research agenda, semi-structured interviews with representatives of the governments of the countries that make up the European Union could be carried out with the aim of deepening existing research designs and innovating research methodologies relevant to the study of the possible relation between ideology and migration.

Such a future research agenda will seek to fill gaps existing in the contemporary literature and will follow premises defended by authors such as Franchino (2009), who affirms that research with focus on domestic institutions as: (i) the legislative and executive brands; (ii) agenda-setting and veto powers; (iii) and the whole decision-making process could explain better how and when immigration policy varies over time, between countries, and even within government coalitions.

Marcelo de Almeida Medeiros (mam14@pq.cnpq.br) é Doutor em Ciência Política pelo Institut d'Études Politiques de Grenoble, Livre-Docente pelo Institut d'Études Politiques de Paris e Professor Titular de Política Internacional Comparada do Departamento de Ciência Política da UFPE.

Dalson Britto Figueiredo Filho (dalsonjus@gmail.com) é Doutor em Ciência Política pela UFPE e Professor Adjunto de Ciência Política do Departamento de Ciência Política da UFPE.

Mariana Batista da Silva (mariana.bsilva@gmail.com) é Doutora em Ciência Política pela UFPE e Professora Adjunto de Ciência Política do Departamento de Ciência Política da UFPE.

Cinthia Regina Campos Ricardo da Silva (cinthyacp@gmail.com) é Doutora em Ciência Política pela UFPE e Professora Adjunto do Instituto de Humanidades e Letras da UNILAB.

Sidney José Vasconcelos Rosendo da Silva (sidney.vasconcelosrosendo@gmail.com) é Bolsista FACEPE de Mestrado junto ao Programa de Pós-Graduação em Ciência Política da UFPE.

Natália Coêlho de Souza Oliveira (nataliacoelho.s@hotmail.com) é Bolsista CAPES de Mestrado junto ao Programa de Pós-Graduação em Ciência Política da UFPE.

\section{References}

Aman, A. C., 1994. Introduction: Migration and Globalization. Indiana Journal of Global Legal Studies, 2(1), pp.1-4.

Anderson, C., 1996. Economics, Politics, and Foreigners: Populist Party Support in Denmark and Norway. Electoral Studies, 15(4), pp.497-511. DOI: 10.1016/S0261-3794(96)00030-3

Arzheimer, K., 2009. Contextual Factors and the Extreme Right Vote in Western Europe, 1980-2002. American Journal of Political Science, 53(2), pp.259-275. DOI: 10.1111/j.1540-5907.2009.00369.x

Bale, T., 2008. Turning Round the Telescope. Centre-right Parties and Immigration and Integration Policy in Europe. Journal of European Public Policy, 15(3), pp.315-330. DOI: 10.1080/13501760701847341

Baumgartner, F.R., \& Jones, B.D. 1993. Agendas and instability in American politics University of Chicago Press.

Bobbio, N., 1994. Direita e Esquerda São Paulo: Editora Unesp.

Boswell, C., 2003. The 'External Dimension' of EU Immigration and Asylum Policy. International Affairs, 79(3), pp.619-638. DOI: $10.1111 / 1468-2346.00326$

Boswell, C. \& Hough, D., 2008. Politicizing Migration: Opportunity or Liability for the Centre-right in Germany? Journal of European Public Policy, 15(3), pp.331-348. DOI: 10.1080/13501760701847382 
Burnell, P., 2009. Refugees. In I. McLean \& A. McMillan, (eds). Oxford Concise Dictionary of Politics. Oxford: Oxford University Press.

Candeias, P., 2016. Product of the Environment: efeitos de interação entre preditores contextuais e individuais de intolerância social na Europa. Revista de Sociologia e Política, 24(57), pp.93-111. DOI: 10.1590/1678-987316245707

Del Sarto, R. A., 2016. Normative Empire Europe: the European Union, its Borderlands, and the 'Arab Spring'. Journal of Common Market Studies, 54(2), pp.215-232. DOI: 10.1111/jcms.12282

Dinas, E., \& Gemenis, K. 2010. Measuring parties' ideological positions with manifesto data: A critical evaluation of the competing methods. Party politics, 16(4), pp.427-450. DOI: 10.1177/1354068809343107

Dummet, M., 2001. On Immigration and Refugees UK: Routledge.

Duncan, F.; Van Hecke, S., 2008. Immigration and the Transnational European Centre-Right: a Common Programmatic Response? Journal of European Public Policy, 15(3), pp.432-452. DOI: 10.1080/13501760701847705

Fisher, S., 2009. Right (-wing). In I. McLean \& A. McMillan, (eds.). Oxford Concise Dictionary of Politics. Oxford: Oxford University Press.

Fitzgerald, J.; Leblang, D. \& Teets, J., 2014. Defying the Law of Gravity: The Political Economy of International Migration. World Politics, 66(3), pp.406-445. DOI: 10.1017/S0043887114000112

Franchino, F., 2009. Perspectives on European Immigration Policy. European Union Politics, 10(3), pp.403-420. DOI: $10.1177 / 1465116509337835$

Garand, J.C.; Xu, P. \& Davis, B., 2017. Immigration Attitudes and Support for the Welfare State in the American Mass Public. American Journal of Political Science, 61(1), pp.146-162. DOI: 10.1111/ajps.12233

Geddes, B., 1995. A Comparative Perspective on the Leninist Legacy in Eastern Europe. Comparative Political Studies, 28(2), pp.239-274. DOI: 10.1177/0010414095028002003

Geddes, A., 2008. Il rombo dei cannoni? Immigration and the Centre-right in Italy. Journal of European Public Policy, 15(3), pp.349-366. DOI: 10.1080/13501760701847416

Gerhards, J. \& Hans, S., 2011. Why not Turkey? Attitudes towards Turkish Membership in the EU among Citizens in 27 European Countries. Journal of Common Market Studies, 49(4), pp.741-766. DOI: 10.1111/j.1468-5965.2010.02155.x

Green-Pedersen, C.; Odmalm, P., 2008. Going different ways? Right-wing parties and the immigrants issues in Denmark and Sweden. Journal of European Public Policy, 15(3), pp.366-381. DOI: 10.1080/13501760701847564

Hinnfors, J.; Spehar, A. \& Bucken-Knapp, G., 2012. The Missing Factor: Why Social Democracy Can Lead to Restrictive Immigration Policy. Journal of European Public Policy, 19(4), pp.585-603. DOI: 10.1080/13501763.2011.607348

Ireland, P.R., 1991. Facing the True 'Fortress Europe': Immigrant and Politics in the EC. Journal of Common Market Studies, 29(5), pp.457-480. DOI: 10.1111/j.1468-5965.1991.tb00403.x

Janz, N., 2016. Bringing the Gold Standard into the Classroom: Replication in University Teaching. International Studies Perspectives, 17(4), pp.392-407. DOI: 10.1111/insp.12104

Joppke, C., 2003. Citizenship between De- and Re-ethnicization. Archives Européennes de Sociologie, 44(3), pp.429-458. DOI: $10.1017 /$ S0003975603001346

Jorge, V.L., Silva, M.G., Faria, A.M.T. \& Ferreira, A.R., 2018. Análise dos programas eleitorais dos candidatos a presidente em 2014: o posicionamento ideológico do PT e do PSDB. Revista de Sociologia e Política, 26(67), pp.1-20. DOI: $10.1590 / 1678987318266701$

Kessler, A.E. \& Freeman, G.P., 2005. Public Opinion in the EU on Immigration from Outside the Community. Journal of Common Market Studies, 43(4), pp.825-850. DOI: 10.1111/j.1468-5965.2005.00598.x

King, G., 1995. Replication, Replication. Political Science \& Politics, 28(3), pp.444-452. DOI: 10.2307/420301

Kogut, B, 1991. Country Capabilities and the Permeability of Borders. Strategic Management Journal, 12(1), pp.33-47. DOI: 10.1002/smj.4250120905

Kuhn, T., 2012. Why Educational Exchange Programmes Miss Their Mark: Cross-Border Mobility, Education and European Identity. Journal of Common Market Studies, 50(6), pp.994-1010. DOI: 10.1111/j.1468-5965.2012.02286.x

Lahav, G., 1997. Ideological and Party Constraints on Immigration Attitudes in Europe. Journal of Common Market Studies, 35(3), pp.377-406. DOI: 10.1111/1468-5965.00067

Lahav, G., \& Messina, A., 2005. The Limits of a European Immigration Policy: Elite Opinion and Agendas within the European Parliament. Journal of Common Market Studies, 43(4), pp. 851-875. DOI: 10.1111/j.1468-5965.2005.00599.x

Laver, M.J., \& Budge, I. 1992. Measuring policy distances and modelling coalition formation. In Party policy and government coalitions. Palgrave Macmillan, London, pp.15-40.

Laver, M., \& Garry, J. 2000. Estimating policy positions from political texts. American Journal of Political Science, 44(3), pp.619-634. DOI: $10.2307 / 2669268$

Lopatin, E., 2013. The Changing Position of the European Parliament on Irregular Migration and Asylum under Co-decision. Journal of Common Market Studies, 51(4), pp. 740-755. DOI: 10.1111/jcms.12015

Markaki, Y. \& Longhi, S., 2012. What Determines Attitudes to Immigration in European Countries? An Analysis at the Regional Level. Norface Migration, Discussion Paper no.32.

Martheler, S., 2008. Nicolas Sarkozy and the Politics of French Immigration Policy. Journal of European Public Policy, 15(3), pp.382-397. DOI: 10.1080/13501760701847614

Messina, A.M., 2007. The Logics and Politics of Post-WWII Migration to Western Europe. Cambridge: Cambridge University Press. 
Munck, R., 2008. Globalisation, Governance and Migration: an Introduction. Third World Quarterly, 29(7), pp.1227-1246. DOI: $10.1080 / 01436590802386252$

Odmalm, P., 2014. The Party Politics of the EU and Immigration UK: Palgrave Macmillan.

Petiteville, F., 2012. Migrations Internationales. In D. Batistella et al. (eds). Dictionnaire de Relations Internationales. Paris: Dalloz.

Reis, R.R. \& Menezes, T., 2014. Direitos Humanos e Refúgio: uma análise sobre o momento anterior à determinação de status de refugiado. Revista de Sociologia e Política, 22 (49), pp.61-83. DOI: 10.1590/S0104-44782014000100004

Schweisguth, É., 2001. Clivage Droite-Gauche. In P. Perrineau \& D. Reynié, eds. Dictionnaire du Vote. Paris: Presses Universitaires de France.

Simmons, A.; Piché, V., 2002. Teaching Migration and Globalisation. Genus, 58(3/4), pp.109-133.

Smith, J., 2008. Towards Consensus? Centre-right Parties and Immigration Policy in the UK and Ireland. Journal of European Public Policy, 15(3), pp.415-431. DOI: 10.1080/13501760701847689

Sredanovic, D., 2016. Political Parties and Citizenship Legislation Change in EU28 Countries, 1992-2013. International Political Science Review, 37(4), pp.438-452. DOI: 10.1177/0192512115584008

Stockemer, D., 2016. Structural Data on Immigration or Immigration Perceptions? What Accounts for the Electoral Success of the Radical Right in Europe? Journal of Common Market Studies, 54(4), pp.999-1016. DOI: 10.1111/jcms. 12341

Thomas, A., 2016. Degrees of Inclusion: Free Movement of Labour and the Unionization of Migrant Workers in the European Union. Journal of Common Market Studies, 54(2), pp. 408-425. DOI: 10.1111/jcms.12284

\section{Newspaper articles}

Migrant crisis: Illegal entries to EU at lowest level in five years. 2019. BBC News. London. $4^{\text {th }}$ Jan. Available in $<$ https://www.bbc.com/news/world-europe-46764500>. Accessed on 20.feb.2020.

\section{Other sources}

Europen Union. 2020. The 27 member countries of the EU. Available at $<$ https://europa.eu/european-union/about-eu/countries_en>. Accessed on 20.feb.2020.

Eurostat 2020. Eurostat: Your key to European statistics. Available at <http://ec.europa.eu/eurostat>. Accessed on 20.feb.2020.

Eur-lex. 2020. $O \quad$ espaço $\quad$ o $a \quad$ cooperação Schengen. Available at $<$ https://eur-lex.europa.eu/legal-conent/PT/TXT/?uri=LEGISSUM:133020>. Accessed on 20.feb.2020.

Frontex 2020. European Border and Coast Guard Agency. Available at $<$ https://frontex.europa.eu/about-frontex/origin-tasks/>. Accessed on 20.feb.2020.

Manifesto database 2020. Manifesto Project. Available at <https://manifesto-project.wzb.eu/>, Accessed on 20.feb.2020.

ParlGov 2016a. ParlGov database. Available at <http://www.parlgov.org/data/table/view_cabinet/>. Accessed on 20.feb.2020.

[QoG database] Teorell, Jan, Stefan Dahlberg, Sören Holmberg, Bo Rothstein, Felix Hartmann \& Richard Svensson. 2015. The Quality of Government Standard Dataset, version Jan15. University of Gothenburg: The Quality of Government Institute. Available at <http://www.qogdata.pol.gu.se/dataarchive/qog_std_jan15.pdf>. Accessed on 20.feb.2020.

Treaty of Lisbon, 2007. Official Journal of the European Union, C306, 150, pp.1-271.

UN High Commissioner for Refugees (UNHCR), The 10-Point Plan in Action, 2016 - Glossary, December 2016. Available at: https://www.refworld.org/docid/59e99eb94.html. Accessed 20. feb. 2020.

World at War UNHCR Global Trends. Forced Displacement in 2014. United Nations High Commissioner for Refugees. Available at $<$ https://www.unhcr.org/556725e69.pdf>. Accessed on 20.feb.2020. 


\section{Padrões de Ideologia e Imigração na União Europeia (1988-2015)}

RESUMO Introdução: A teoria aponta para a existência de possíveis elos entre a ideologia partidária e as políticas públicas migratórias, afirmando que, em princípio, valores associados à direita tendem a, com base no nacionalismo, restringir mais as dinâmicas de imigração do que aquelas ligadas à axiologia da esquerda, ancorada no universalismo. A ideologia partidária afeta os padrões de imigração na União Europeia? Este artigo testa a hipótese de que quanto maiores os valores na ideologia (governos de direita), menor o número de migrantes para aquele país específico. Materiais e Métodos: $\mathrm{O}$ desenho da pesquisa replica dados secundários do ParlGov e do Comparative Manifesto Project. Também usamos dados do Global Bilateral Migration Database e do Bilateral Migration Matrix. Além da estatística descritiva, examinamos a relação entre ideologia e fluxos migratórios. Nós estimamos dois modelos de regressão para lidar com as seguintes variáveis dependentes: migração líquida e população de refugiados por país ou território de asilo. Resultados: Usando dados do ParlGov, Manifesto e QoG, a estatística descritiva enfatizou uma cartografia muito heterogênea de características políticas, ideologia e migração nos países da União Europeia. A primeira análise de regressão usando dados agregados sugere que quanto maiores os valores de ideologia por país (orientada para a direita), menor o número de pessoas que entram naquele país. No entanto, os resultados de nossa análise estatística desagregada, particularmente o Modelo 1, não indicam nenhum efeito da ideologia de gabinete sobre a migração líquida. No que diz respeito à categoria de refugiados para imigrantes, nossos resultados sugerem que os governos nacionais orientados para a direita são menos receptivos aos refugiados. O Modelo 2 afirmou que um aumento de um ponto na ideologia está associado a uma redução média de 13\% no número de refugiados que entram no país. Discussão: Nosso estudo avança o entendimento atual sobre a relação entre ideologia partidária e padrões de imigração. No entanto, os resultados da análise de regressão mostram evidências limitadas em favor da nossa hipótese de que quanto mais à direita o governo no espectro ideológico, menor o número de refugiados aceitos no país. No entanto, esta análise destina-se apenas a mostrar uma relação entre ideologia e migração. Reivindicações causais devem ser interpretadas com cautela.

PALAVRAS-CHAVE: União Europeia; governo; ideologia; migração; partidos políticos.

This is an Open Access article distributed under the terms of the Creative Commons Attribution Non-Commercial License which permits unrestricted non-commercial use, distribution, and reproduction in any medium provided the original work is properly cited.

A produção desse manuscrito foi viabilizada através do patrocínio fornecido pelo Centro Universitário Internacional Uninter à Revista de Sociologia e Política. 